\title{
Is there enough habitat for reintroduced populations of the Lesser Kestrel? A case study in eastern Spain
}

\author{
IRENE PÉREZ, JOSÉ CARLOS NOGUERA and EDUARDO MÍNGUEZ
}

\section{Summary}

The Lesser Kestrel Falco naumanni is one of the most endangered birds in Europe. Spanish populations have suffered large declines and disappeared from large areas of former distribution, thus leading to many reintroduction programmes. One of the main factors that could affect the population growth of reintroduced populations is the availability of suitable habitat for breeding and foraging. We investigated whether nest site availability is a limiting factor for a newly established population of Lesser Kestrels in eastern Spain. We developed univariate models to understand the relationship between building characteristics (area, height, roof condition, etc.) and occupancy and abundance of Lesser Kestrels, and multivariate models to predict the availability of nest-sites. Our results showed that the species selected medium-sized buildings with extensive land use in the surrounding area and an absence of trees. In addition, Lesser Kestrel abundance was explained by roof condition and distance to the nearest building. Multivariate models predicted that most of the buildings were not suitable for nesting by Lesser Kestrels and thus population growth may be limited due to lack of nest sites. Lack of suitable nest sites, conspecific attraction and Allee effects are all processes that may be limiting, resulting in the low population and colony sizes that were found and predicted. Based on this, we recommend the provision of nest boxes, the use of special tiles and the construction of breeding towers to improve building quality and therefore increase colony size. We also critically question the use of reintroduction projects to restore locally extinct populations for two reasons. First in this case the reintroduced population is near some larger colonies and there is a strong tendency for Lesser Kestrels to move from small to large colonies. Secondly, in a general strategy for the conservation of Lesser Kestrels, conservation of the main colonies is the priority rather than dedicating human and economic resources on manipulative actions for the establishment of new colonies.

\section{Resumen}

El Cernícalo Primilla Falco naumanni es una de las aves más amenazadas de Europa. Las poblaciones españolas han sufrido un importante declive y han desapareciendo de extensas zonas, lo que ha originado la puesta en marcha de varios programas de reintroducción. Uno de los principales factores que puede afectar el crecimiento poblacional de las poblaciones reintroducidas es la disponibilidad de hábitat adecuado para la alimentación y la cría. Hemos investigado si la disponibilidad de lugares de nidificación es un factor limitante para la reciente población establecida de Cernícalo Primilla en el este de España. Desarrollamos modelos univariantes para entender la relación entre las características de las edificaciones (área, altura, estado del tejado, etc.) y la ocupación y abundancia de cernícalos primilla, y modelos multivariantes para predecir la disponibilidad de lugares de nidificación. Nuestros resultados mostraron que la especie seleccionó edificaciones de mediano tamaño, con usos del suelo extensivos en el área de alrededor 
a las edificaciones y ausencia de árboles. Además de estas características, el estado del tejado y la distancia a la edificación más cercana explicaron la abundancia de Cernícalo Primilla. Los modelos multivariantes predijeron que la mayoría de las edificaciones no eran adecuadas para la nidificación del cernícalo primilla y, por tanto, el crecimiento poblacional podría estar limitado por la falta de lugares de nidificación. Esto, junto con los riesgos de atracción conespecífica y efecto Allee, son procesos que pueden estar limitando a la población, dando lugar al bajo tamaño poblacional y tamaño de las colonias encontrado y predicho. Basado en nuestros resultados, recomendamos la colocación de cajas nido y tejas especiales y la construcción de primillares para mejorar la calidad de las edificaciones y, por tanto, incrementar el tamaño de la colonia. Además, cuestionamos críticamente el uso de proyectos de reintroducción para la recuperación de poblaciones extintas localmente por dos motivos principales. Primero, en este caso de estudio la población reintroducida está cerca de colonias de mayor tamaño y hay una tendencia fuerte de que los cernícalos primilla se muevan de pequeñas a grandes colonias. En segundo lugar, en una estrategia general de conservación del cernícalo primilla, es prioritario la conservación de las principales colonias, en lugar de dedicar recursos humanos y económicos en actuaciones manipulativas para el establecimiento de nuevas colonias.

\section{Introduction}

Reintroductions of living organisms have become an important and frequently used tool in conservation management to help in the recovery, establishment or re-establishment of viable populations of threatened species (Griffith et al. 1989, Dodd and Seigel 1991, Wolf et al. 1996, Fischer and Lindenmayer 2000). In recent decades, a large number of reintroduction programmes have been developed worldwide, resulting in some successes but many failures (Griffith et al. 1989, Dodd and Seigel 1991, Wolf et al. 1996, Fischer and Lindenmayer 2000). Therefore, monitoring is critical to evaluate the outcome of reintroduction programmes and to determine the precise factors that underlie their success or failure.

Predictive models are being increasingly used in reintroduction programmes both to identify suitable locations (e.g. Pearce and Lindenmayer 1998, Thatcher et al. 2006, Olsson and Rogers 2009), and to predict population growth and range expansions of released species (e.g. Carroll et al. 2003, Kramer-Schadt et al. 2005). While factors such as stochastic mortality or sex ratio are important to success during the establishment phase, habitat factors are most likely to determine the spread of the reintroduced population once it has been established, (Bright and Smithson 2001, Le Gouar et al. 2008). After the establishment phase, information collected during the first years of the reintroduction programme may be used to refine potential habitat models as well as to predict population development (South et al. 2000). Monitoring may allow the design of suitable management actions and thus the development of an adaptive management strategy that is essential in reintroduction programmes (Sarrazin and Barbault 1996).

Lesser Kestrel Falco naumanni is a small colonial bird of prey typically inhabiting Palearctic pseudo-steppes during the breeding season. This species nests in crevices or cavities of farm buildings, old churches or castles (Cramp and Simmons 1980). Lesser Kestrel was once one of the most abundant birds of prey in Europe but underwent a large population decline during the second half of the 2oth century (Biber 1990). Since the 1990s, populations are recovering in Spain and southern France (e.g. Prugnolle et al. 2003, Ortego et al. 2007). As in other European countries, breeding populations in Spain suffered large population declines between 1960 and 1980 (Tucker and Heath 1994). Consequently, several reintroduction programmes were established (e.g. Pomarol 1991, Serrano and Delgado 2004, this study). In eastern Spain, the species was wiped out at the beginning of the 1990 and the local government began a reintroduction programme in 1997 (Alberdi 2001). Between 1997 and 2001, 184 chicks from the west of Spain were released in a small agricultural valley (10,00o ha; $38^{\circ} 94^{\prime} \mathrm{N}, \mathrm{OI}^{\circ} 11^{\prime} \mathrm{W}$ ) with adequate foraging habitat (traditionally-farmed cereals with field margins and small patches of natural vegetation) (Donázar et al. 1993, Tella et al. 1998, Tella and Forero 2000, Franco and 
Sutherland 2004). According to the hacking protocol (Sherrod et al. 1982), kestrel chicks were placed in hack boxes at the reintroduction site at 20-24 days old, and after a few days of acclimatisation, boxes were opened and the birds were allowed to leave. The reintroduction programme was successful and this new colony is now established. Ten years after the reintroduction programme, it is important to assess whether the availability of nest sites may limit the expansion (numerical and spatial) of the newly established colony. The shortage of suitable nesting sites is a key factor limiting population size in many hole-nesting birds (Village 1983, Newton 1994, 1998), although it has been identified as important in only some populations of Lesser Kestrels (Forero et al. 1996, Franco et al. 2005). However, the availability of suitable nest-sites can be crucial for reintroduced populations of Lesser Kestrels if this factor is not adequately foreseen. In our case study, only 1o nest-boxes were provided in the hacking area, thus Lesser Kestrels have to nest on isolated buildings in the reintroduction area, although no previous assessment of the suitability of the buildings for nesting was carried out. Other authors have studied the characteristics and availability of buildings for the 'natural' expansion of colonies by comparing the buildings with and without colonies, and concluded that Lesser Kestrels selected buildings with many roof and wall cavities that are surrounded by extensive cereal and fallow fields (Franco et al. 2005). We use the information collected during the monitoring of the reintroduction programme of Lesser Kestrels in eastern Spain to determine the characteristics of buildings that make them suitable for reintroduced Lesser Kestrels. We use this information to predict the availability of nesting sites for the population growth and based on these results, we make recommendations for conservation management.

\section{Methods}

\section{Field methods and habitat variables}

During the 2007 breeding season (from the end of February to the beginning of July), we surveyed all buildings in an area within a maximum radius of $7,700 \mathrm{~m}$ around the reintroduction site to determine whether they were occupied by Lesser Kestrels and the number of breeding pairs per occupied building. This spatial limit is the median distance covered by dispersing Lesser Kestrels (Serrano et al. 2001, Serrano et al. 2003). Buildings were considered to be occupied if one or more pairs were seen entering a cavity and when a male brought food to feed a female (Ursúa et al. 2004a).

To identify the characteristics of buildings that make them suitable for Lesser Kestrels, we surveyed both occupied and non-occupied buildings in the study area $(n=76)$. The mean distance between the hacking site and the buildings included in the study area was 3,600 $\mathrm{m}$ (range $=0-7,700 \mathrm{~m} ; \mathrm{SE}=1,808 \mathrm{~m}$ ). Buildings were characterised according to 11 variables (Table 1 ). The percentage of suitable foraging habitat around each building was obtained in a previous study in the reintroduction area (authors' unpublished data) by means of the Savage Selectivity Index (Manly et al. 1993). This index is expressed as $\omega_{i}=U_{i} / p_{i}$, where $U_{i}$ is the proportion of observations recorded in any one land-use and $p_{i}$ is the proportion of that land-use in the study area. Our results, which agree with other studies (Donázar et al. 1993, Tella et al. 1998, Tella and Forero 2000), showed that Lesser Kestrels selected fallow land, stubble and cereals as foraging habitat.

\section{Statistical analysis}

To relate the occupancy and abundance of Lesser Kestrels with building characteristics, we used logistic regression models with a binomial error and a logistic link function for our binary dependent variable (occupied/unoccupied building) and Poisson regression models with a Poisson error and a logarithm function for our count dependent variable (number of breeding pairs per building). We developed univariate and multivariate models between the predictor variables and 
Table 1. Independent variables analysed for suitability of isolated houses/buildings for Lesser Kestrels.

\begin{tabular}{llc}
\hline Variable & Variable description & Units \\
\hline INHA & Occupancy (inhabited/livestock, temporarily inhabited, unused, neglected) & $1-4$ \\
AREA & Building basal area & $\mathrm{m}^{2}$ \\
$M H$ & Maximum height of the highest roof & $\mathrm{m}$ \\
$m H$ & Minimum height of the shortest roof & $\mathrm{m}$ \\
CON & Roof condition (o $\%$, o-33\%, 34-66\%, 67-100\% in ruins) & $1-4$ \\
TILE & Tile type (arabic, flat ceramic tile, and corrugated asbestos and cement & $1-3$ \\
& $\quad$ roofing material) & $\%$ \\
TREE & Percentage of the perimeter of the building with trees within $20 \mathrm{~m}$ & $\mathrm{~m}$ \\
DINHA & Minimum distance to the nearest inhabited house & $\mathrm{m}$ \\
DISHAT & Distance to the hacking site & $\mathrm{m}$ \\
FORAG & Minimum distance to the nearest occupied building by lesser kestrels & $\%$ \\
\hline
\end{tabular}

both dependent variables. Univariate models illustrate the relationship between the presence and abundance of the species and each of the predictor variables independently. Multivariate models consider the influence and co-linearity of multiple factors by jointly modelling multiple response variables. The result is a model for each one of the dependent variables with the maximum number of significant response variables and with the larger explained deviance. The resulting multivariate models were used to predict the availability of Lesser Kestrel nest-sites in the reintroduction area. The inclusion of variables into the multivariate models was made step-by-step using Akaike's information criterion (AIC) (Burnham and Anderson 2002). However, to increase the parsimony of our multivariate models, variables were added only if they resulted in a $>1 \%$ increase in the explained deviance. The linear and quadratic forms of all explanatory variables were tested.

We used the probability value that maximised the sum of sensitivity and specificity (Liu et al. 2005) as the threshold value of occurrence for the models. Model values were transformed from quantitative values to a qualitative range of habitat quality and abundance. In the transformations of both models, the first category included all values ranging from o to the threshold value of occurrence, which thus represented the characteristics of suboptimal buildings in which the species is not expected to nest. The remaining values were proportionally grouped in equal intervals that represent classes of buildings with different quality for the nesting of the species.

We used the AUC values (area under the receiver operating characteristic [ROC] curve) to assess the predictive ability of the logistic model (Fielding and Bell 1997). The Poisson model was evaluated using Pearson and Spearman coefficients. All analyses were conducted using the R statistical package (R Development Core Team 2008).

\section{Results}

In 2007,20 buildings were occupied ( $26.32 \%$ of the total number of buildings surveyed) by 40 Lesser Kestrel pairs, with a mean abundance of 2.4 pairs per building (range $=1-5$; $\mathrm{SE}=1.6$ ).

\section{Univariate models}

The chances of a building being occupied by Lesser Kestrels in the study area increased with suitable foraging habitat around the colony (FORAG) and with the building basal area (AREA), to an optimum of c.150 m, but decreased with the presence of trees (TREE) (Table 2, Figure I). The probability of being occupied decreased to almost o when more than $50 \%$ of the perimeter of the building had trees (Figure 1 ).

The results obtained in the abundance model (Table 2) predicted that Lesser Kestrel abundance was highest in buildings with a basal area of $\mathrm{c} .150 \mathrm{~m}^{2}$, with a distance of $\mathrm{c} .800 \mathrm{~m}$ to the nearest 
Table 2. Univariate GLM that relates occupation and abundance of the Lesser Kestrel with the characteristics of buildings. $R^{2}=\%$ of explained deviance. Type = type of response with the larger value of explained variance: " $+^{\prime \prime}$ linear positive, "-" linear negative, " $++^{\prime \prime}$ quadratic positive. $P={ }^{*}<0.05,{ }^{* *}<$ 0.01, $* * *<0.001$.

\begin{tabular}{lllll}
\hline Independent variable & Dependent variable & $\mathrm{R}^{2}$ & Type & $P$ \\
\hline Occupation & AREA (quadratic) & 17.06 & ++ & 0.0082 \\
Occupation & TREE & 8.24 & - & 0.0172 \\
Occupation & FORAG & 7.94 & + & 0.0133 \\
Abundance & AREA (quadratic) & 29.60 & ++ & $<0.001$ \\
Abundance & CON (quadratic) & 16.47 & ++ & 0.0005 \\
Abundance & TREE (quadratic) & 12.68 & ++ & 0.029 \\
Abundance & DINHA (quadratic) & 19.27 & ++ & 0.0019 \\
Abundance & FORAG & 13.89 & + & $<0.001$ \\
\hline
\end{tabular}

inhabited building (DINHA) and with c.25\% of the roof in ruins (CON) (Figure 1). The predicted abundance decreased to almost $\mathrm{o}$ when more than $50 \%$ of the roof was in ruins and when more than $50 \%$ of the perimeter had trees (Figure 1 ). The abundance of kestrels increased linearly with suitable foraging habitat around the colony (FORAG).

\section{Multivariate models}

The predictive occupancy model incorporated the variables AREA and TREE and explained $23.85 \%$ of the deviance (Table 3). The threshold value of occurrence was 0.35 (Table 4). Table 4 shows the grouping of the buildings within the classes of probability of occupation by Lesser Kestrels.

\section{(a) Probability of occupancy}
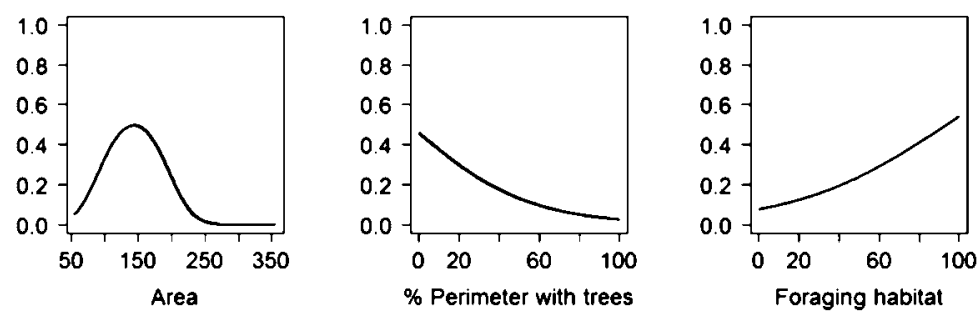

\section{(b) Predicted abundance}
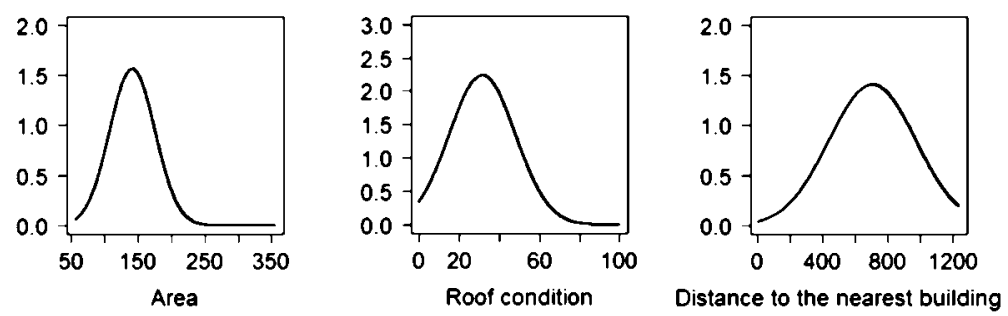

Figure 1. Probability of occupancy (a) of Lesser Kestrels in relation to the independent variables AREA (left), TREE (centre), and FORAG (right); and predicted abundance (pairs per building) (b) in relation to AREA (left), CON (centre), and DINHA (right). See Table 1 for an explanation of the independent variables. 
Table 3. Multivariate GLM for the occupation and abundance of Lesser Kestrels in the reintroduction area.

\begin{tabular}{|c|c|c|c|}
\hline & Model structure & Parameter estimate & Deviance \\
\hline \multicolumn{4}{|l|}{ Probability of occupation } \\
\hline & Constant & -6.4532 & \\
\hline & AREA & 0.0977 & \\
\hline & AREA (quadratic) & -0.0003 & 16.25 \\
\hline & TREE & -0.0360 & 23.85 \\
\hline \multicolumn{4}{|l|}{ Abundance data } \\
\hline & Constant & -6.6630 & \\
\hline & $A R E A$ & 0.0853 & \\
\hline & AREA (quadratic) & -0.0003 & 29.60 \\
\hline & $\mathrm{MH}$ & -0.2999 & $37 \cdot 46$ \\
\hline & $\mathrm{CON}$ & 0.0837 & \\
\hline & $\mathrm{CON}$ (quadratic) & -0.0015 & 47.07 \\
\hline & TREE & 0.0735 & \\
\hline & TREE (quadratic) & -0.0017 & $54 \cdot 58$ \\
\hline & DINHA & 0.0068 & \\
\hline & DINHA2 (quadratic) & -0.000005 & 58.14 \\
\hline
\end{tabular}

Like the predictive occupancy model, the abundance model incorporated the variables AREA and TREE. In addition, this model incorporated the variables CON, DINHA, and the maximum height of the highest roof $(\mathrm{MH})$ (Table 3). The resulting model explained $58.14 \%$ of the deviance. According to the predictions of the model, $10.53 \%$ of the buildings could have a higher number of Lesser Kestrel breeding pairs than they actually had (Table 4).

Taking into account the predictions of both multivariate models, 1o unoccupied buildings in the study area had a medium to high probability of being occupied by Lesser Kestrels and so the population could increase by eight new breeding pairs.

The evaluation of the model of occupancy showed AUC values of 0.8232 . The relationship between predicted abundance and current abundance of Lesser Kestrels was statistically significant $(P<$ o.01 $)$ and positive with Pearson and Spearman correlation coefficients of 0.7272 and 0.5519 , respectively.

\section{Discussion}

\section{Building selection}

According to our results, Lesser Kestrels reintroduced in eastern Spain selected medium-sized buildings as nesting sites, with extensive land use in the area surrounding the colony site and with

Table 4. Qualitative classes of the presence and abundance models. The number of the observed and predicted buildings in each class is given. In the observed buildings row, suboptimal and optimal rows means buildings with presence and absence of Lesser Kestrels respectively.

\begin{tabular}{|c|c|c|c|c|c|c|}
\hline \multirow[t]{2}{*}{ Classes } & \multicolumn{3}{|l|}{ Occupancy } & \multicolumn{3}{|c|}{ Abundance } \\
\hline & Range & $\begin{array}{l}\text { Observed } \\
\text { buildings }\end{array}$ & $\begin{array}{l}\text { Predicted } \\
\text { buildings }\end{array}$ & Range & $\begin{array}{l}\text { Observed } \\
\text { buildings }\end{array}$ & $\begin{array}{l}\text { Predicted } \\
\text { buildings }\end{array}$ \\
\hline Suboptimal & $0-0.3553$ & 57 & 36 & $\mathrm{o}$ & 57 & 56 \\
\hline Optimal & $>0.3553$ & 19 & 40 & $>0$ & 19 & 20 \\
\hline Low & $0.3553-0.5702$ & - & 17 & $1-2$ & 12 & 17 \\
\hline Medium & $0.5702-0.7851$ & - & 19 & 3 & o & 2 \\
\hline High & $0.7851-1$ & - & 4 & $>3$ & 7 & 1 \\
\hline
\end{tabular}


few or no trees. In addition, Lesser Kestrel abundance was explained by roof condition and distance to the nearest occupied building. The preference of Lesser Kestrels for extensive land use around nest-sites has also been found by other authors both on a regional scale (Bustamante 1997) and at a colony level (Franco et al. 2005). This preference is likely to be linked to foraging habitat because Lesser Kestrels forage in extensive fields where prey items are abundant (Tella et al. 1998, Ursúa et al. 2004b, Rodríguez et al. 2006). Building size and roof condition may be related to the availability of cavities for nesting, i.e. good roof condition and small buildings decrease the availability of cavities for nesting. Other authors have also detected the preference of Lesser Kestrels for buildings with many roof and wall cavities (Franco et al. 2005). The avoidance of large buildings does not have a clear explanation; this response may be masking the correlation of this variable with other explanatory factors, e.g. in our study area most of the largest buildings did not have a roof with an adequate design for the nesting of the species. In relation to the preference of buildings without trees, this response may be linked to the avoidance of predators, such as domestic cat Felis catus, Black Rat Rattus rattus, and Stone Marten Martes foina (Negro and Hiraldo 1993). Other studies have concluded that Lesser Kestrels avoid predation by selecting the highest positions in farmhouse roofs (Negro and Hiraldo 1993). In our case study, height of building was not important as it was not included in the list of significant variables in the univariate models but did appear in the abundance multivariate model. Finally, the selection of buildings located at a moderate distance from other unoccupied buildings shows the preference of Lesser Kestrels for rural landscapes with scattered buildings.

Among the factors detected that determined the presence and abundance of Lesser Kestrels, surrounding habitat and roof condition are of special concern. On one hand, habitat loss, mainly due to agricultural intensification, is the main threat to the conservation of the Lesser Kestrel (Donázar et al. 1993, Parr et al. 1995, Bustamante 1997, Tella et al. 1998, Tella and Forero 2000, Franco and Sutherland 2004). Currently in the study area, traditional extensive agriculture (cereal plantations) is being transformed into unsuitable foraging habitat for the species (vine, sunflower plantations and fruit trees) and other unproductive habitats (urbanisation and installation of solar farms). This change in land use leads to a lowering of habitat quality and thus it is predicted that it will prevent population growth. On the other hand, in other colonies in the interior of the Iberian Peninsula, building condition is one of the threats to the species due to the possibility of collapse of roofs or whole buildings (Tella et al. 1993, Franco et al. 2005). However, in the study area as well as in other coastal areas in the Mediterranean, the problem of building condition is more related to building and roof rehabilitation with unsuitable materials and designs. In fact, after this study, some roofs in the study area were rehabilitated and prevented the Lesser Kestrels from nesting.

\section{Nest site availability}

Multivariate models predicted that the availability of adequate buildings for nesting as well as nesting sites within buildings may limit the population growth of the reintroduced population studied. Almost half of the buildings in the reintroduction area were predicted to be unsuitable for nesting by Lesser Kestrels and the reintroduced population may show only slight population growth, with a total of 48 predicted breeding pairs, and with most of the buildings containing a low number of breeding pairs $(<3)$. However, it has to be noted that a potential problem with our models is that they are based on data from an expanding population. Thus, currently unoccupied buildings may either be unsuitable for nesting or, if the population is not at carrying capacity, as the population increases birds may start to occupy these other buildings once the best ones are fully occupied. This would lead to an underestimate of the quality of buildings and thus of the population growth of the reintroduced population. Thus, it would be advisable to update the results of this study in order to validate the models and predictions obtained. 
Despite this, the size of the reintroduced population and colonies seem to be smaller than what would be expected after to years since reintroduction and there may be several causes. The expansion of Lesser Kestrel colonies is often through despotic behaviour (Serrano and Tella 2007) which changes the spatial distribution of colonies by increasing the frequency of small colony sizes over large ones ( $>$ 1o breeding pairs) (Jovani et al. 2008). Accordingly, the fact that all our colonies were small, with $<5$ breeding pairs per colony, may be indicating that the buildings in the reintroduction area do not have enough nest sites of suitable quality.

An Allee effect (Serrano et al. 2005) and conspecific attraction (Serrano et al. 2001, 2003, 2004, Serrano and Tella 2003) may also be slowing the growth of this reintroduced population. These processes may cause the migration of the breeding birds from the reintroduction site to other larger colonies, independently of the quality of the habitat of the natal colony. In an area c.25 km around the reintroduction area there are other dense populations of Lesser Kestrels (e.g. Núñez et al. 2009) that may attract reintroduced kestrels. Although most individual Lesser Kestrels tend to settle close to their natal colony, juveniles may move large distances ( $>100 \mathrm{~km}$ ) (Serrano et al. 2003) with a frequency higher than would be expected in a philopatric species (Alcaide et al. 2009). Future studies should try to elucidate the influence of these processes on the population growth of this reintroduced population. This may improve the predictions of population growth made in this study.

\section{Management recommendations}

According to our results, the limits for the growth of this reintroduced population seem to be related to the quality of the buildings, but also to the dispersal behaviour of the species. The relatively low population size of this reintroduced colony, and its low expected growth, could inhibit its long-term viability. Improving the quality of buildings may facilitate population growth. To this end, in buildings where other conditions are adequate (i.e. absence of trees and presence of extensive agriculture), nest boxes and special tiles could be installed. These measures have been successfully developed in other Iberian colonies of Lesser Kestrels (Pomarol 1996, Franco et al. 2005, Catry et al. 2009) and in colonies of other small falcons (Hamerstrom et al. 1973, Fargallo et al. 2001). Also, in areas with suitable habitat but without buildings, breeding towers may be constructed. In addition, special attention must be given when restoring old farmhouses to avoid the destruction of possible nesting cavities. Measures of rural development and habitat protection could be important to restrict the loss of suitable foraging habitat for the species. These measures may also help other threatened species in the reintroduction area, such as steppe birds (e.g. Little Bustard Tetrax tetrax, Pin-tailed Sandgrouse Pterocles alchata and Black-bellied Sandgrouse P. orientalis) (Urios et al. 1991).

However, considering the strong emigration of Lesser Kestrels from small to large relatively close colonies (Serrano et al. 2005), the utility of reintroducing colonies in areas close to other natural long-established population, as our case study, is highly doubtful. Furthermore, the reintroduction project in the study area aims to restore a locally extinct population of Lesser Kestrels while the main colonies of this species in the interior of the Iberian Peninsula continue to be threatened by habitat loss through agricultural intensification (Tella et al. 1998, Tella and Forero 2000). In a general strategy for the conservation of Lesser Kestrels, conservation of the main colonies is the priority rather than dedicating human and economic resources on manipulative actions for the establishment of new colonies. Unfortunately, many reintroduction programmes are based on local policies designed and implemented by local authorities, with a limited understanding of the status and conservation needs of the species at an ecological and ecosystem scale and no consideration of the metapopulation dynamics of the populations. This analysis continues the open debate about the true need for some reintroduction programmes and the importance of having a global vision of the species status and conservation (Frazer 1992, Meffe 1992). 


\section{Acknowledgements}

This research was funded by ENESTAR S.A. We wish to thank José Daniel Anadón for his assistance in data analysis. He and José Antonio Sánchez-Zapata made useful comments on an earlier version of the manuscript. We are indebted to the referees of this manuscript for helpful comments that have much improved the paper. Mercedes Alberdi, Miguel Blázquez and Juan Manuel Pérez-García helped with fieldwork. We also thank all the inhabitants of the study area for their support during fieldwork.

\section{References}

Alberdi, M. (2001) Proyecto de reintroducción del cernícalo primilla (Falco naumanni) en la Comunidad Valenciana. Pp. $377-383$ in J. F. Garcés and M. Corroto eds. Biología y conservación del Cernícalo Primilla. Madrid, Spain: Consejería de Medio Ambiente de la Comunidad de Madrid and GREFA.

Alcaide, M., Serrano, D., Tella, J. L. and Negro, J. J. (2009) Strong philopatry derived from capture-recapture records does not lead to fine-scale genetic differentiation in lesser kestrels. J. Anim. Ecol. 78: $468-$ 475 .

Biber, J. P. (1990) Action plan for the conservation of western lesser kestrel Falco naumanni populations. Cambridge, UK: ICBP.

Bright, P. W. and Smithson, T. J. (2001) Biological invasions provide a framework for reintroductions: selecting areas in England for pine marten releases. Biodivers. Conserv. 10: 1247-1265.

Burnham, K. P. and Anderson, D. R. eds. (2002) Model selection and multi-model inference. A practical information-theoretic approach. New York, USA: Springer-Verlag.

Bustamante, J. (1997) Predictive models for lesser kestrel Falco naumanni distribution, abundance and extinction in southern Spain. Biol. Conserv. 80: 153-160.

Carroll, C., Phillips, M. K., Schumaker, N. H. and Smith, D. W. (2003) Impacts of landscape change on wolf restoration success: Planning a reintroduction program based on static and dynamic spatial models. Conserv. Biol. 17: 536-548.

Catry, I., Alcazar, R., Franco, A. M. A. and Sutherland, W. J. (2009) Identifying the effectiveness and constraints of conservation interventions: A case study of the endangered lesser kestrel. Biol. Conserv. 142: 2782-2791.

Cramp, S. and Simmons, K. E. L. eds. (1980) The birds of the western Palearctic. Vol. 2. Oxford, UK: Oxford University Press.

Dodd, C. K. and Seigel, R. A. (1991) Relocation, repatriation, and translocation of amphibians and reptiles: Are they conservation strategies that work? Herpetologica 47: $336-350$.

Donázar, J. A., Negro, J. J. and Hiraldo, F. (1993) Foraging habitat selection, land-use changes and population decline in the lesser kestrel Falco naumanni. J. Appl. Ecol. 30: 515-522.

Fargallo, J. A., Blanco, G., Potti, J. and Viñuela, J. (2001) Nestbox provisioning in a rural population of Eurasian kestrels: breeding performance, nest predation and parasitism. Bird Study 48: 236-244.

Fielding, A. H. and Bell, J. F. (1997) A review of methods for the assessment of prediction errors in conservation presence/absence models. Environ. Conserv. 24: 38-49.

Fischer, J. and Lindenmayer, D. B. (2000) An assessment of the published results of animal relocations. Biol. Conserv. 96: 1-11.

Forero, M. G., Tella, J. L., Donázar, J. A. and Hiraldo, F. (1996) Can interespecific competition and nest site availability explain the decrease of lesser kestrel Falco naumanni populations? Biol. Conserv. 78: 289-293.

Franco, A. M. A. and Sutherland, W. J. (2004) Modelling the foraging habitat selection of lesser kestrels: conservation implications of European agricultural policies. Biol. Conserv. 120: 63-74.

Franco, A. M. A., Marques, J. T. and Sutherland, W. F. (2005) Is nest-site availability limiting lesser kestrel populations? A multiple scale approach. Ibis 147: 657-666. 
Frazer, N. B. (1992) Sea turtle conservation and halfway technology. Conserv. Biol. 6: 179-84.

Griffith, B., Scott, J. M., Carpenter, J. W. and Reed, C. (1989) Translocation as a species conservation tool: status and strategy. Science 245: 477-480.

Hamerstrom, F., Hamerstrom, F. N. and Hart, J. (1973) Nest boxes: An effective management tool for kestrels. J. Wildl. Manage. 37: 400-403.

Jovani, R., Serrano, D., Ursúa, E. and Tella, J. L. (2008) Truncated power laws reveal a link between low level behavioral processes and grouping patterns in a colonial bird. PLoS ONE 3: e1992. doi: 10.1371/journal.pone. ooo1992.

Kramer-Schadt, S., Revilla, E., Wiegand, T. and Breitenmoser, U. (2005) Fragmented landscapes, road mortality and patch connectivity: modelling influences on the dispersal of Eurasian lynx. J. Appl. Ecol. 41: 711-723.

Le Gouar, P., Robert, A., Choisy, J., Henriquet, S., Lecuyer, P., Tessier, C. and Sarrazin, F. (2008) Roles of survival and dispersal in reintroduction success of griffon vulture (Gyps fulvus). Ecol. Appl. 18: 859-872.

Liu, C., Berry, P. M., Dawson, T. P. and Pearson, R. G. (2005) Selecting thresholds of occurrence in the prediction of species distributions. Ecography 28: $385-$ 393.

Manly, B. F. J., McDonald, L. L. and Thomas, D. L. (1993) Resource selection by animals. London, UK: Chapman \& Hall.

Meffe, G. K. (1992) Techno-arrogance and halfway technologies: Salmon hatcheries on the Pacific coast of North America. Conserv. Biol. 6: 350-354.

Negro, J. J. and Hiraldo, F. (1993) Nest-site selection and breeding success in the lesser kestrel Falco naumanni. Bird Study 40: 115-119.

Newton, I. (1994) The role of nest sites in limiting the numbers of hole-nesting birds: a review. Biol. Conserv. 70: 265-276.

Newton, I. (1998) Population limitation in birds. London, UK: Academic Press.

Núñez, C., Vélaz, M. and Catalán, A. E. (2009) Seguimiento de la población reproductora de cernícalo primilla en la provincia de Albacete. Situación de la especie en la Manchuela. Alaxarch: Revista de Estudios de la Manchuela 3. (Available at www. revistaalaxarch.es/primilla.htm).

Olsson, O. and Rogers, J. (2009) Predicting the distribution of a suitable habitat for the white stork in southern Sweden: Identifying priority areas for reintroduction and habitat restoration. Anim. Conserv. 12: 62-70.

Ortego, J., Aparicio, J. M., Calabuig, G. and Cordero, P. J. (2007) Increase of heterozygosity in a growing population of lesser kestrels. Biol. Lett. 3: 585-588.

Parr, S., Collin, P., Silk, S., Wilbraham, J., Williams, N. P. and Yarar, M. (1995) A baseline survey of lesser kestrels Falco naumanni in Central Turkey. Biol. Conserv. 72: 45-53.

Pearce, J. and Lindenmayer, D. B. (1998) Bioclimatic analysis to enhance reintroduction biology of the endangered helmeted honeyeater (Lichenostomus melanops cassidix) in southeastern Australia. Restor. Ecol. 6: 238-243.

Pomarol, M. (1991) Lesser kestrel (Falco naumanni) recovery project in Catalonia. Pp. 24-28 in M. K. Nicholls and R. Clarke eds. Biology and conservation of small falcons. Proceedings of the 1991 Hawk and Owl Trust Conference. London, UK: The Hawk and Owl Trust.

Pomarol, M. (1996) Artificial nest structure design and management implications for the lesser kestrel (Falco naumanni). J. Raptor Res. 30: 169-172.

Prugnolle, F., Pilard, P., Brun, L. and Tavecchia, G. (2003) First-year and adult survival of the endangered lesser kestrel Falco naumanni in southern France. Bird Study 50: 68-72.

R Development Core Team (2008). R: A language and environment for statistical computing. Vienna, Austria: R Foundation for Statistical Computing. ISBN 3-90005107-o, URL http://www.R-project.org.

Rodríguez, C., Johst, K. and Bustamante, J. (2006) How do crop types influence breeding success in lesser kestrels thought prey quality and availability? A modelling approach. J. Appl. Ecol. 43: 587597. 
Sarrazin, F. and Barbault, R. (1996) Reintroduction - challenges and lessons for basic ecology. Trends. Ecol. Evol. 11: $474-478$.

Serrano, D. and Delgado, J. M. (2004) Cría en cautividad y reintroducción. Pp. 100-113 in El cernícalo primilla en Andalucía. Bases ecológicas para su conservación. Sevilla, Spain: Consejería de Medio Ambiente. Junta de Andalucía.

Serrano, D. and Tella, J. L. (2003) Dispersal within a spatially structured population of lesser kestrels: the role of spatial isolation and conspecific attraction. J. Anim. Ecol. 72: $400-410$.

Serrano, D. and Tella, J. L. (2007) The role of despotism and heritability in determining settlement patterns in the colonial lesser kestrel. Am. Nat. 169: E53-E67.

Serrano, D., Forero, M. G., Donázar, J. A. and Tella, J. L. (2004) The role of dispersal and conspecific cues on breeding site selection and colony dynamics of lesser kestrels. Ecology 85: 3438-3447.

Serrano, D., Oro, D., Ursúa, E. and Tella, J. L. (2005) Colony size selection determines adult survival and dispersal preferences: Allee Effects in a colonial bird. Am. Nat. 166: 22-31.

Serrano, D., Tella, J. L., Donázar, J. A. and Pomarol, M. (2003) Social and individual features affecting natal dispersal in the colonial lesser kestrel. Ecology 84: 30443054 .

Serrano, D., Tella, J. L., Forero, M. G. and Donázar, J. A. (2001) Factors affecting breeding dispersal in the facultatively colonial lesser kestrel: individual experience vs. conspecific cues. J. Anim. Ecol. 70: 568-578.

Sherrod, S. K., Heinrich, W. R., Burnham, W. A., Barclay, J. H. and Cade, T. J. eds. (1982) Hacking: a method for releasing peregrine falcons and other birds of prey. Ithaca, New York: The Peregrine Fund.

South, A., Rushton, S. and Macdonald, D. (2000) Simulating the proposed reintroduction of the European beaver (Castor fiber) to Scotland. Biol. Conserv. 93: 103-116.
Tella, J. L. and Forero, M. G. (2000) Farmland habitat selection of wintering lesser kestrels in a Spanish pseudosteppe: implications for conservation strategies. Biodivers. Conserv. 9: 433-441.

Tella, J. L., Forero, M. G., Hiraldo, F. and Donázar, J. A. (1998) Conflicts between lesser kestrel conservation and European agricultural policies as identified by habitat use analyses. Conserv. Biol. 12: 593-604.

Tella, J. L., Pomarol, M., Muñoz, E. and López, R. (1993) Importancia de la conservación de los mases para las aves en los Monegros. Alytes 6: 335-350.

Thatcher, C. A., Van Manen, F. T. and Clark, J. D. (2006) Identifying suitable sites for Florida panther reintroduction. J. Wildl. Manage. 70: 752-763.

Tucker, G. M. and Heath, M. F. eds. 1994. Birds in Europe: Their conservation status. Cambridge, UK: BirdLife International. (BirdLife Conservation Series, 3).

Urios, V., Escobar, J. V., Pardo, R. and Gómez, J. A. eds. (1991) Atlas de las aves nidificantes de la Comunidad Valenciana. Valencia, Spain: Conselleria d'Agricultura i Pesca. Generalitat Valenciana.

Ursúa, E., Tella, J. L., Serrano, D., Seoane, J., Gajón, A. and Forero, M. G. (2004a) Protocolos de seguimiento de poblaciones de cernícalo primilla. Pp. 45-52 in Actas del VI Congreso Nacional sobre el Cernícalo Primilla. Zaragoza, Spain: Gobierno de Aragón.

Ursúa, E., Serrano, D. and Tella, J. L. (2004b) Does land irrigation actually reduce foraging habitat for breeding lesser kestrels? The role of crop types. Biol. Conserv. 122: 643-648.

Village, A. (1983) The role of nest-site availability and territorial behaviour in limiting the breeding density of kestrels. J. Anim. Ecol. 52: 635-645.

Wolf, C. M., Griffith, B., Reed, C. and Temple, S. A. (1996) Avian and mammalian translocations: update and reanalysis of 1987 survey data. Conserv. Biol. 10: 1142-1154. 


\section{IRENE PÉREZ*}

Universidad Miguel Hernández. Dpto. Biología Aplicada. Área de Ecología. Avda. Universidad s/n Edif. Torreblanca. 03202 Elche (Alicante), Spain.

\section{JOSÉ CARLOS NOGUERA}

Dpto. Ecoloxia e Bioloxía Animal, Edificio de Ciencias Experimentales, Universidad de Vigo. 36310 Vigo (Pontevedra), Spain.

\section{EDUARDO MÍNGUEZ}

Parque Natural Serra Gelada y su Entorno Litoral. Paseo de la Carretera 34. 03501 Benidorm (Alicante), Spain.

*Author for correspondence; e-mail: irene.perez@umh.es

Received 13 January 2010; revision accepted 14 June 2010;

Published online 30 November 2010 